\title{
The Comparison between Microcredit Finance and Community Development Finance to Alleviate the Extreme Poverty in Bangladesh: A Case Study of Shibalaya
}

\author{
Idris Ali, Ashiqun Nabi \\ Lecturer in Finance, Department of Business Administration, School of Business and Economics, Manarat International University, Dhaka, \\ Bangladesh
}

\section{Email address:}

idris_ukf@yahoo.com (I. Ali), ashiq_480@yahoo.com (A. Nabi)

\section{To cite this article:}

Idris Ali, Ashiqun Nabi. The Comparison between Microcredit Finance and Community Development Finance to Alleviate the Extreme Poverty in Bangladesh: A Case Study of Shibalaya. International Journal of Economics, Finance and Management Sciences.

Vol. 3, No. 3, 2015, pp. 172-178. doi: 10.11648/j.ijefm.20150303.14

\begin{abstract}
This paper explains the comparison between Microcredit Finance and Community Development Finance to alleviate the extreme poverty in Bangladesh. According to the theory, Microcredit is a small loan (microloan) to be provided to those who have less collateral, it supports entrepreneurship and alleviates poverty through empowering women and uplifting entire communities by extension. On the other hand, Community Development Finance (CDF) focuses on personal lending and business development efforts in local communities by individual person or institution. The study obtained the opinions of 50 families from Shibalaya Thana under Manikgonj district in Bangladesh through a survey on the impact of Microcredit Finance and Community Development Finance to alleviate their extreme poverty. To conduct this study, qualitative (expert interview, focus group discussion) and quantitative methods was used. The study is based on primary data collection through questionnaires and Statistical Package for Social Science (SPSS) was used to analyze the data. The study found that both of these mechanisms have a significant role to alleviate the poverty who could utilize the loan properly. However, these two mechanisms for alleviating poverty have some demerits as well. Finally, this study came up with some recommendation to get more benefit from these two mechanisms to alleviate poverty in Bangladesh. Nevertheless, the results of the study are constrained by the size of the sample, area and robustness of the analysis.
\end{abstract}

Keywords: Microcredit Finance, Community Development Finance, Poverty Alleviation

\section{Introduction}

In recent years, there are lots of mechanisms have been used to eradicate the extreme poverty in various countries. But none of them actually eradicated the poverty in developing countries. In fact, we cannot eradicate the poverty as a whole rather we can just reduce or alleviate it. Nevertheless, "Poverty" and "Poverty Alleviation" are often heard catchwords in this contemporary world. Poverty is a multidimensional phenomenon and depends on the context and perception that one is looking at. Shil, N.C (2009) mentioned in her article that, Professor Muhammad Yunus (Bangladesh), the Noble Peace Price winner in 2006, has said that, "Poverty" is that characteristic of being in a state of joblessness, illiteracy, landlessness, homelessness, lack of adequate capital, facilities and food to earn a decent living and also powerlessness. Poverty alleviation is, therefore, the act of reducing the scourges of the above conditions of an individual or community. According to a statistics, about 1.6 billion people on the globe are in absolute poverty and the number is rising (Jammeh, 2002). All these poor people need help and poverty alleviation projects got priority at the time of fund allocation through budget in most of the developing countries. In this regards, Micro finance can be a critical element on effective poverty alleviation strategy. Improved access and efficient provision of savings, credits and insurance facilities in particular can enable the poor to smooth their consumption, manage risk better; built assets gradually develop micro enterprises, enhance their income earning capacity and enjoy improved quality life (Rubambey, 2001).

On the other hand, Community development finance (CDF) means, lending money to businesses and people who struggle to get finance from high street banks. They are social 
enterprises that invest in customers and communities. CDF creates jobs and help businesses to start and grow. They help people to pay bills, meet unexpected expenses or improve their home. They help people who may otherwise use high cost credit, such as payday lenders. They provide support as well as finance, giving extra help and advice where it's needed. There are number of countries are using Community Development Finance to help the poor people. Usually there is a lot of Community Development Finance Institutions (CDFI) which are working to alleviate the poverty by lending money to the poor people. But in Bangladesh, we have few Community Development Finance which are not directed by any organization or institution rather these are controlled by some self-centered individual person who lend money to the poor people not for the profit (interest) rather to change their poor life into better life. In this mechanism, community based poor people get the loan without any interest or collateral and uses this loan for small business, education, agriculture or even only for surviving in this world. However, Institutions similar in purpose exist around the world, such as Grameen Bank in Bangladesh, though they are not generally called Community Development Finance Institutions, but are described by other terms such as microfinance institutions or social banks.

In a nutshell, this research focuses on the comparison between Micro Credit Finance and Community Development Finance to alleviate the poverty in Bangladesh especially in Shibalaya. It exposes to an extent the impact of these two mechanisms for alleviating the poverty and also reveals expectations from the people/clients in order to change their living style to a better position by these two popular mechanisms.

\section{Literature Review}

Murdoch and Haley mentioned that 'there is ample evidence to support the positive impact of microfinance on poverty reduction as it relates to the first six of the seven Millennium Goals' (Murdoch and Haley 2002:5). According to their study clients who participate in microfinance programs have enjoyed increased household income, better nutrition and health, the opportunity to achieve higher education, a decrease in vulnerability to economic shock, greater empowerment, and in some cases, the ability to completely lift themselves and their families out of poverty. Other scholars (Wright 2000, Simanowitzand Walter 2002, Cherston and kuhn 2002), also argued that microfinance contributes to increased income, consumption smoothing, better health and nutrition, improvement in school attendance and empowerment. All of these benefits are interconnected; the improvement of one will invariably have a positive effect on the others. The combined enhancement in all areas of life brings a marked increase in living conditions for the poor and a new message of hope for the eventual reduction of poverty.

In addition to that, according to Mosley (1999), microfinance makes a considerable contribution to the reduction of poverty through its impact on income and also has a positive impact on asset level. But the mechanism through which poverty reduction works varies between institutions. Generally, institutions that give, on average, smaller loans reduce poverty much more by lifting borrowers above the poverty line, whilst institutions giving larger loans reduce it much more by expanding the demand for labor amongst poor people. According to Van Maanen, 'microfinance is bringing credit, savings and other essential financial services within the reach of millions of people who are too poor to be served by regular banks, in most cases because they are unable to offer sufficient collateral' (Maanen 2004:17). However, according to David Holme (2000:79), although some scholars support that microfinance has positive economic and social impacts on the poor, microfinance has negative impacts on the poor clients as well. There are also in between who supports the positive impact but not necessarily for the poorest, as claimed.

On the other hand, a few Community Development Corporations and a group of revolving loan funds, to make loans to businesses in order to promote economic development (Grossman, et. al, 1998). Moreover, there are some Community Development Finance Institution (CDFIs) are trying to promote economic growth and job creation in low-income areas, stabilizing population declines in distressed communities, improving the availability and quality of community facilities in under-served markets, increasing the number of businesses owned by women and ethnic minorities, and promoting the growth of businesses that do not harm the environment (Caskey \& Holister, 2001). However, CDFIs make loans and equity investments, collect deposits, and offer various checking and savings accounts. They expand their efforts with assorted education and counseling activities related to their financial products and services. They do not build projects, but instead help to finance them.

\section{Objectives of the Study}

The key objective of this paper is to compare between Microcredit Finance (MCF) and Community Development Finance (CDF) to alleviate the extreme poverty in Bangladesh. The specific objectives are:

1) to determine the impact of $\mathrm{CDF}$ and MCF to alleviate the poverty in Bangladesh,

2) to estimate the preference of the clients among these two mechanisms to improve their lifestyle.

3) to identify the better solution to alleviate extreme poverty in Bangladesh.

\section{Methodology}

\subsection{Study Area}

The study is confined to and covers the relevant study areas. It has covered only one place of Bangladesh which is Shibalaya upazila of Manikgonj district under Dhaka division where both Community Development Finance and traditional 
Micro-credit operated by different NGOs like Grameen Bank, BRAC, ASA, SPUS etc. Although the study was confined to limited areas, the survey has generated useful information and insights, supported by qualitative data. An individual person, named Mr. Ratan Kazi, a non-residential Bangladeshi (NRB) business man living in England regularly disburses interest free loan among poor and extreme poor people in Shibalaya upazila of Manikgonj district under Dhaka division which is the birth place of Mr. Ratan Kazi in order to alleviate the poverty of his locality as a responsibility of a wealthy person to the community.

\subsection{Study Design}

Both quantitative and qualitative techniques were used to collect in-depth information on selected indicators related to the study. Qualitative tools were used in the present analysis, to capture the wide range of perspectives and dynamics.

Key Variable: A set of key variables and indicators shown in Table-01 was encountered for the present study.

Table 01. Key variables and indicators.

\begin{tabular}{|c|c|c|c|}
\hline Variables & Indicators & $\begin{array}{l}\text { Source }(\text { Respondent }=\mathbf{R}, \text { Researcher } \\
\text { Observation }=\text { RO Secondary }=S)\end{array}$ & Method \\
\hline Demographic & age, gender, marital status, family size,. & $\mathrm{R}, \mathrm{RO}$ & Survey \\
\hline Socio-cultural and economic & $\begin{array}{l}\text { education, average monthly family income, occupation, } \\
\text { economic better off or not. }\end{array}$ & $\mathrm{R}, \mathrm{RO}$ & $\begin{array}{l}\text { Survey and } \\
\text { observation }\end{array}$ \\
\hline $\begin{array}{l}\text { Client, client type and loan } \\
\text { source preferences, }\end{array}$ & $\begin{array}{l}\text { micro-credit, community finance, both, regular, irregular, } \\
\text { rare, defaulter. }\end{array}$ & $\mathrm{R}, \mathrm{RO}$ & $\begin{array}{l}\text { Survey and } \\
\text { observation }\end{array}$ \\
\hline Loan objective & $\begin{array}{l}\text { Agriculture, business, marriage expenses of children, } \\
\text { educational expenses of children, medical expenses, asset } \\
\text { purchase, surviving, migration, and multi-purpose. }\end{array}$ & $\mathrm{R}, \mathrm{RO}$ & Survey \\
\hline Client's consent & Strongly disagree, disagree, neutral, agree, strongly agree. & $\mathrm{R}, \mathrm{RO}$ & Survey \\
\hline
\end{tabular}

To satisfy the objectives, both primary and secondary sources of data have been exploited. Researchers follow survey method to collect primary data. A well-structured and pre-tested questionnaire has been used to collect primary data. Exactly 50 samples were selected as per the Simple Random Sampling procedures from Shibalaya Upazila of Manikgonj district. Most of the questions are asked to the respondents in five points Likert scale, where 5 indicates strongly agree, 4 indicates agree, 3 indicates neutral, 2 indicates disagree and 1indicates strongly disagree. Target population of the study is the borrowers who have experience of borrowing from both Community Development Finance (CDF) and Micro-credit (MC). Collected data have been analysed in accordance of the objective of the study and the nature of data. Statistical Package for Social Science (SPSS) was used for the purpose of analysis of data. The secondary sources of data include different books, journals, articles, dissertation; annual reports and different websites relevant to the topics.

To compare between Microcredit Finance and Community Development Finance to alleviate the extreme poverty in Bangladesh following ten hypotheses have been made.

Hypothesis - 1:

$\mathrm{H}^{0}$ : Interest and cost free CDF loan does not contribute more than traditional Micro-credit to alleviate extreme poverty of borrowers although CDF loan removes burden of interest and other cost.

$\mathrm{H}_{1}^{1}$ : Interest and cost free CDF loan contributes more than traditional Micro-credit to alleviate extreme poverty of borrowers as CDF loan removes burden of interest and other cost.

Hypothesis -2 :

$\mathrm{H}_{2}^{0}$ : Close monitoring on usage of borrowed fund by CDF does not ensure proper utilization of borrowed fund and also does not help to increase income and reduce poverty, but traditional MCF does so.
$\mathrm{H}_{2}^{1}$ : Close monitoring on usage of borrowed fund by CDF ensures proper utilization of borrowed fund and helps to increase income and reduce poverty, but traditional MCF does not so.

Hypothesis - 3:

$\mathrm{H}_{3}^{0}$ : Interest free feature of CDF loan does not attract pious Muslim borrowers to take loan from CDF and thus does not help them in reducing their poverty; and traditional $\mathrm{MCF}$ with interest charge does not discourage pious Muslim borrowers to take loan from MCF and thus does not prevent them to reduce their poverty.

$\mathrm{H}_{3}^{1}$ : Interest free feature of CDF loan attracts pious Muslim borrowers to take loan from CDF and thus help them in reducing their poverty; on the other hand, traditional $\mathrm{MCF}$ with interest charge discourages pious Muslim borrowers to take loan from MCF and thus prevents them to reduce their poverty.

Hypothesis - 4:

$\mathrm{H}_{4}^{0}$ : CDF is not more capable than a traditional MCF to select right borrower due to the familiarity among community members, thus cannot ensure high performance and recovery of CDF loan which further cannot ensure smooth operation of CDF and alleviation of poverty.

$\mathrm{H}_{4}^{1}$ : CDF is more capable than a traditional MCF to select right borrower due to the familiarity among community members, thus ensures high performance and recovery of CDF loan which further ensure smooth operation of CDF and indirectly helps to alleviate poverty of the borrowers.

Hypothesis - 5:

$\mathrm{H}^{0}{ }_{5}$ : Comparatively flexible terms and conditions of CDF loan do not facilitate more than traditional MCF to alleviate extreme poverty of borrower.

$\mathrm{H}_{5}^{1}$ : Comparatively flexible terms and conditions of $\mathrm{CDF}$ loan facilitate more than traditional MCF to alleviate extreme poverty of borrower. 
Hypothesis - 6:

$\mathrm{H}_{6}^{0}$ : Comparatively, large loan size of traditional MCF does not contribute more than comparatively small loan size of CDF to alleviate extreme poverty of borrower.

$\mathrm{H}_{6}{ }_{6}$ : Comparatively, large loan size of traditional MCF contributes more than comparatively small loan size of $\mathrm{CDF}$ to alleviate extreme poverty of borrower.

Hypothesis - 7:

$\mathrm{H}_{7}^{0}$ : Well organized traditional MCF does not contribute more than less organized CDF to alleviate poverty by disbursing loan in the time of need of the borrowers.

$\mathrm{H}_{7}^{1}$ : Well organized traditional MCF contributes more than less organized CDF to alleviate poverty by disbursing loan in the time of need of the borrowers.

Hypothesis - 8:

$\mathrm{H}_{8}^{0}$ : Monthly loan repayment (instalment) systems of CDF do not facilitate more than weekly loan repayment (instalment) systems of traditional MCF to alleviate extreme poverty of borrower.

$\mathrm{H}^{1}$ : Monthly loan repayment (instalment) systems of $\mathrm{CDF}$ facilitate more than weekly loan repayment (instalment) systems of traditional MCF to alleviate extreme poverty of borrower.

Hypothesis - 9:

$\mathrm{H}_{9}^{0}$ : You are not more benefitted from $\mathrm{CDF}$ than traditional MCF in case of reducing your poverty.
$\mathrm{H}_{9}^{1}$ : You are more benefitted from $\mathrm{CDF}$ than traditional $\mathrm{MCF}$ in case of reducing your poverty.

Hypothesis - 10:

$\mathrm{H}^{0}{ }_{10}$ : CDF is not a better solution than traditional MCF to alleviate extreme poverty in Bangladesh

$\mathrm{H}^{1}{ }_{10}$ : CDF is a better solution than traditional MCF to alleviate extreme poverty in Bangladesh.

Hypotheses have been analysed in 5\% level of significance and assumed the null hypothesis as the average response of the population which is 3.25 or 2.75 and it has not been increased unless it is proved, thus it can be written as:
$\mathrm{H}^{0}: \mu \leq 3.25$
$\mathrm{H}^{1}: \mu>3.25$

As $\mathrm{H}^{1}$ is one sided, we shall determine the rejection region applying one-tailed test at 5\% level of significance and it comes to as under, using table of $\mathrm{t}$ or $\mathrm{z}$ test. In this research, $\mathrm{t}$-test has been applied for testing hypotheses.

\section{Analysis and Discussion}

\subsection{Demographic and Socio-economic Analysis of Respondents}

Gender: Out of the 50 samples, 40 respondents that mean $80 \%$ of the respondents are male and 10 respondents that mean $20 \%$ of the respondents are female. (Table 02 )

Table 02. Demographic and socio-economic details of the respondents taken as a sample.

\begin{tabular}{|c|c|c|c|}
\hline Variables & Classification & No. of respondent & Percentage \\
\hline \multirow{2}{*}{ Gender } & Male & 40 & $80 \%$ \\
\hline & Female & 10 & $20 \%$ \\
\hline \multirow{4}{*}{ Age Distribution } & $21-40$ & 9 & $18 \%$ \\
\hline & $41-50$ & 15 & $30 \%$ \\
\hline & $51-60$ & 22 & $44 \%$ \\
\hline & $60+$ & 4 & $8 \%$ \\
\hline \multirow{2}{*}{ Marital Status } & Married & 47 & $94 \%$ \\
\hline & Divorced & 1 & $2 \%$ \\
\hline \multirow{3}{*}{ Family Size } & Small & 30 & $60 \%$ \\
\hline & Medium & 19 & $38 \%$ \\
\hline & Large & 1 & $2 \%$ \\
\hline \multirow{4}{*}{ Education } & Illiterate & 21 & $42 \%$ \\
\hline & Primary & 16 & $32 \%$ \\
\hline & High School or SSC & 9 & $18 \%$ \\
\hline & College or HSC & 4 & $8 \%$ \\
\hline \multirow{8}{*}{ Occupation } & Business & 16 & $32 \%$ \\
\hline & Labor & 5 & $10 \%$ \\
\hline & Service & 3 & $6 \%$ \\
\hline & Rickshaw Puller & 4 & $8 \%$ \\
\hline & Driving & 3 & $6 \%$ \\
\hline & Housewife & 2 & $4 \%$ \\
\hline & Unemployed & 1 & $2 \%$ \\
\hline & Multi-occupation & 11 & $22 \%$ \\
\hline \multirow{4}{*}{ Family Income Per Month } & Less than TK. 5,000 & 7 & $14 \%$ \\
\hline & Tk. $6,000-10,000$ & 26 & $52 \%$ \\
\hline & Tk. $11,000-15,000$ & 10 & $20 \%$ \\
\hline & Above Tk. 15,000 & 7 & $14 \%$ \\
\hline \multirow{3}{*}{ Client Type } & Regular & 24 & $48 \%$ \\
\hline & Irregular & 25 & $50 \%$ \\
\hline & Defaulter & 1 & $2 \%$ \\
\hline
\end{tabular}


Age: $18 \%$ of the respondents are between the ranges of 21 $40.30 \%$ of the respondents are between the ranges of $41-50$. $44 \%$ of the respondents are between the ranges of 51-60. $8 \%$ of the respondents are above 60 .

Marital Status: $94 \%$ of the respondents are married, $4 \%$ of the respondents are unmarried and only $2 \%$ of the respondents are divorced.

Family Size: $60 \%$ of the respondents' family size is small, $38 \%$ of the respondents' family size is medium, and $2 \%$ of the respondents' family size is large.

Education: $42 \%$ of the respondents are illiterate, $32 \%$ of the respondents have primary school education, only $18 \%$ of the respondents have high school education, and only $8 \%$ of the respondents have college education.

Occupation: $10 \%$ of the respondents' occupation is agriculture, $32 \%$ of the respondents' occupation is business, $10 \%$ of the respondents' occupation is labor, $6 \%$ of the respondents' occupation is service, $8 \%$ of the respondents' occupation is rickshaw pulling, $6 \%$ of the respondents' occupation is driving mini-car, only $4 \%$ of the respondents' occupation is housewife, only $2 \%$ of the respondents' is unemployed and $22 \%$ of the respondents' have multi occupation.

Family Income per Month: 14\% of the respondents' family income per month is less than Tk.5000, 52\% of the respondents' family income per month is in the range of between Tk.6000 - Tk. 10000, 20\% of the respondents' family income per month is in the range of between Tk.11000 - Tk. 15000, and 14\% of the respondents' family income per month is above Tk. 15000 .

Client Type: $48 \%$ of the respondents are regular borrower, $50 \%$ of the respondents are irregular borrower and only $2 \%$ respondents are defaulter.

\subsection{Hypothesis - Test Analysis}

It is shown from the analysis that $1.2 \%$ of the respondents that mean a negligible portion of them strongly disagreed about the contribution of CDF. $10.4 \%$ of the respondents that mean a negligible portion of them disagreed in this respect. $35 \%$ of the respondents were neutral on this topic. $44.2 \%$ of the respondents agreed and $9.2 \%$ of the respondents strongly agreed that means a large portion of them agreed on this issue. Finally, it has been found from the analysis that most of the respondents agreed and strongly agreed that the CDF significantly contributes to alleviate extreme poverty of borrowers.

Table 03. Summery of questionnaire data.

\begin{tabular}{|c|c|c|c|c|c|c|}
\hline Question No. & Strongly disagree & Disagree & Neutral & Agree & Strongly Agree & Mean \\
\hline 1 & 0 & 5 & 17 & 24 & 4 & 3.56 \\
\hline 2 & 0 & 4 & 16 & 30 & 0 & 3.52 \\
\hline 3 & 1 & 10 & 22 & 10 & 7 & 3.24 \\
\hline 4 & 0 & 3 & 18 & 24 & 5 & 3.62 \\
\hline 5 & 2 & 3 & 13 & 25 & 7 & 3.64 \\
\hline 6 & 0 & 2 & 19 & 23 & 6 & 3.66 \\
\hline 7 & 2 & 7 & 21 & 19 & 1 & 3.20 \\
\hline 8 & 1 & 15 & 25 & 9 & 0 & 3.84 \\
\hline 9 & 0 & 3 & 12 & 27 & 8 & 3.80 \\
\hline 10 & 0 & 0 & 12 & 30 & 8 & 3.92 \\
\hline Total & $6=1.2 \%$ & $52=10.4 \%$ & $175=35 \%$ & $221=44.2 \%$ & $46=9.2 \%$ & \\
\hline
\end{tabular}

Source: Field Survey, 2014

It is revealed out that $\mathrm{CDF}$ significantly contributes to alleviate extreme poverty of borrowers by providing interest and cost free CDF loan, monitoring usage of borrowed fund, attracting pious Muslim borrowers to take inters free CDF loan, selecting appropriate borrowers, issuing CDF loan at a flexible terms and conditions, extending long time gap to repay borrowed money - specifically extending monthly loan repayment opportunity instead of weekly installment like a traditional micro credit loan. It is also revealed out that micro-credit significantly contributes to alleviate extreme poverty of borrowers by disbursing loan in the time of necessity of the borrowers and supplying large amount of fund.

From the $\mathrm{T}$ test it is found from the table- 02 that calculated value of $\mathrm{T}$ is greater than the tabulated value for all the attributes. That means all the null hypotheses are rejected and all the alternative hypotheses are accepted. Therefore, the following statements are valid as all these statements are tested in the befitted way. 
Table 04. Hypotheses test of different attributes.

\begin{tabular}{|c|c|c|c|c|c|c|}
\hline Attributes & Mean & $\begin{array}{l}\text { Standard } \\
\text { Deviation } \\
\end{array}$ & $\begin{array}{l}\text { Computed } \\
\text { value of } t\end{array}$ & P Value & $\begin{array}{l}\text { Critical value of } @ 5 \% \text { level } \\
\text { of significance }\end{array}$ & Result \\
\hline $\begin{array}{l}\text { Interest \& cost free CDF loan contribute more to } \\
\text { alleviate poverty }\end{array}$ & 3.54 & .788 & 2.603 & .012 & 1.96 & rejected \\
\hline Monitoring usage of borrowed fund & 3.52 & 646 & 2.953 & .005 & 1.96 & rejected \\
\hline $\begin{array}{l}\text { Pious Muslim borrowers are interested in CDF loan } \\
\text { than micro - credit }\end{array}$ & 3.24 & 1.001 & 3.461 & .001 & 1.96 & rejected \\
\hline $\mathrm{CDF}$ is more capable to select appropriate borrower. & 3.62 & 3.62 & 3.475 & .001 & 1.96 & rejected \\
\hline Flexible terms and conditions of CDF & 3.64 & .942 & 2.926 & .005 & 1.96 & rejected \\
\hline Large loan size of micro-credit & 3.66 & .745 & 3.890 & .000 & 1.96 & rejected \\
\hline $\begin{array}{l}\text { Micro-credit finance disburses loan in the time of } \\
\text { need of the borrower. }\end{array}$ & 3.20 & .857 & 3.712 & .001 & 1.96 & rejected \\
\hline Monthly loan repayment (installment) of CDF & 3.84 & .738 & 5.650 & .000 & 1.96 & rejected \\
\hline $\begin{array}{l}\text { Borrowers benefitted more from CDF loan in case of } \\
\text { poverty alleviation }\end{array}$ & 3.80 & .782 & 4.970 & .000 & 1.96 & rejected \\
\hline $\begin{array}{l}\text { CDF is the better solution to alleviate poverty in } \\
\text { Bangladesh than micro-credit }\end{array}$ & 3.92 & .634 & 7.476 & .000 & 1.96 & rejected \\
\hline
\end{tabular}

Source: Calculated table.

Interest and cost free CDF loan contributes more than traditional Micro-credit to alleviate extreme poverty of borrowers as CDF loan removes burden of interest and other cost. Close monitoring on usage of borrowed fund by CDF ensures proper utilization of borrowed fund and thus it helps to increase income and reduce poverty, but in case of traditional MCF there is no such positive outcome due to lack of monitoring. Interest free feature of CDF loan attracts pious Muslim borrowers to take loan from CDF and thus help them in reducing their poverty; on the other hand, traditional $\mathrm{MCF}$ with interest charge discourages pious Muslim borrowers to take loan from MCF and thus prevents them to reduce their poverty. Comparatively, $\mathrm{CDF}$ is more capable than a traditional $\mathrm{MCF}$ to select right borrower due to the familiarity among community members, thus ensures high performance and recovery of CDF loan which further ensure smooth operation of CDF and indirectly helps to alleviate poverty of the borrowers. Comparatively flexible terms and conditions of CDF loan facilitate more than traditional MCF to alleviate extreme poverty of borrower. Monthly loan repayment (instalment) systems of CDF facilitate more than weekly loan repayment (instalment) systems of traditional MCF to alleviate extreme poverty of borrower. Borrowers are more benefitted from $\mathrm{CDF}$ than traditional MCF in case of reducing their poverty. Although large loan size of traditional MCF contributes more than comparatively small loan size of CDF and well organized traditional MCF contributes more than less organized CDF to alleviate poverty by disbursing loan in the time of need of the borrowers. But, finally it is proved that $\mathrm{CDF}$ is a better solution than traditional MCF to alleviate extreme poverty in Bangladesh.

\section{Major Findings of the Study}

After extensive analysis the subject matter of the study, following major issues have found from this study.

- Interest and cost free CDF loan contribute more than traditional Micro-credit to alleviate extreme poverty of borrowers although CDF loan removes burden of interest and other cost.

- Close monitoring on usage of borrowed fund by CDF ensure proper utilization of borrowed fund and also does not help to increase income and reduce poverty, but traditional MCF does so.

- Interest free feature of CDF loan attract pious Muslim borrowers to take loan from CDF and thus does not help them in reducing their poverty; and traditional MCF with interest charge does not discourage pious Muslim borrowers to take loan from MCF and thus does not prevent them to reduce their poverty.

- $\quad \mathrm{CDF}$ is more capable than a traditional MCF to select right borrower due to the familiarity among community members, thus ensure high performance and recovery of CDF loan which further ensure smooth operation of CDF and alleviation of poverty.

- Comparatively flexible terms and conditions of CDF loan facilitate more than traditional $\mathrm{MCF}$ to alleviate extreme poverty of borrower.

- Comparatively, large loan size of traditional MCF contribute more than comparatively small loan size of CDF to alleviate extreme poverty of borrower

- Well organized traditional MCF contribute more than less organized CDF to alleviate poverty by disbursing loan in the time of need of the borrowers.

- Monthly loan repayment (instalment) systems of CDF facilitate more than weekly loan repayment (instalment) systems of traditional MCF to alleviate extreme poverty of borrower.

- You are more benefitted from CDF than traditional $\mathrm{MCF}$ in case of reducing your poverty.

- $\mathrm{CDF}$ is a better solution than traditional MCF to alleviate extreme poverty in Bangladesh

\section{Recommendations}

- Micro Credit Finance (MCF) would be very useful mechanism to alleviate the poverty in Bangladesh if the clients could repay the loan on time with less interest 
within the stipulated time.

- $\quad$ On the other hand, since it does not require any sort of interest and collateral, Community Development Finance (CDF) would be very useful mechanism to alleviate the poverty in Bangladesh if this CDF can be spread out throughout Bangladesh by making it institutionalized and with proper monitoring system.

- Wealthy people of the society should come forward to alleviate the extreme poverty through CDF mechanism since it is more effective to alleviate poverty.

- Government, NGOs and policy maker of Bangladesh should take necessary initiatives to spread out all over the Bangladesh

- Government can provide special incentives (e.g. tax exemption, CIP announcement) to motivate wealthy people to donate in $\mathrm{CDF}$.

\section{Concluding Remarks}

"Poverty" seems to be very difficult spot which cannot be removed from the clothes! If we can at least make it fade, which might be a great achievement for the developing countries like Bangladesh since the people are not educated, too much ignorant, lazy to overcome their poverty. However, taking the research findings and suggestions into action by the concerned people, it can be hoped that, Micro Credit Finance (MCF) would be very useful mechanism to alleviate the poverty in Bangladesh if the clients could repay the loan on time with less interest within the stipulated time. On the other hand, since it does not require any sort of interest and collateral, Community Development Finance (CDF) would be very useful mechanism to alleviate the poverty in Bangladesh if this $\mathrm{CDF}$ can be spread out throughout Bangladesh by making it institutionalized and with proper monitoring system.

\section{References}

[1] Caskey, John P. and Hollister, Robinson (2001). Business Development Financial Institutions: Theory, Practice, and Impact. Institute for Research on Poverty Discussion Paper no. 1240-01.
[2] Cheston, S. and L. Kuhn (2002) 'Empowering Women through Microfinance', Micro credit Summit Campaign, Pathways out of Poverty. Kumarian: Bloomfield, CT.

[3] Grossman, Brian, Levere, Andrea and Marcoux, Kent. (1998). Counting on Local Capital. Corporation for Enterprise Development: Washington D.C.

[4] Hulme, D. (2000) 'Impact assessment methodologies for microfinance: Theory, experience and better practice'. World Development, Vol. 28, No. 1, pp79-98

[5] Jammeh, M. E. (2002). Access to Finance in the Artisanal Fisheries Sub-Sector of the Gambia. Presentation Made at the Workshop on Artisanal Fisheries and the World Markets (1112 April 2002): Administration Of Agricultural Credit Schemes with Reference to the AFDP Credit Program.

[6] Maanen, van Gert (2004) Micro credit: Sound Business or Development Instrument, Voorburg, The Netherlands.

[7] Mosley, P. (2001). Microfinance and Poverty in Bolivia, Journal of Development Studies, Vol. 37 (4), 101-132.

[8] Murdoch, J. and B. Haley (2002) 'Analysis of the Effects of Microfinance on Poverty Reduction' NYU Wagner Working Paper No. 1014.

[9] Rubambey, G. (2001), "Conference proceeding of the fifth Annual International Conference on Entrepreneurship and Small Business Development".

[10] Shil,N.C (2009)."Micro Finance for Poverty Alleviation: A Commercialized View" International Journal of Economics and Finance, Vol.1, No.2 p.p 191

[11] Simanowitz, A. and A. Walter (2002) 'Ensuring Impact: Reaching the Poorest while Building Financially SelfSufficient Institutions, and Showing Improvement in the Lives of the Poorest Women and Their Families'. In Sam DaleyHarris, Ed. Micro credit Summit Campaign, Pathways Out of Poverty. Kumarian: Bloomfield, CT.

[12] Wright, Graham A. N. (2000) Microfinance Systems: Designing Quality Financial Services for the Poor. Zed Books Ltd. London \& New York, and The University Press Limited: Dhaka. 